\title{
The biotechnology and marketing interface: Functional integration using mechanistic and holographic responses to environmental turbulence
}

Pierre Berthon, Leyland Pitt, Deon Nel, Esmail Salehi-Sangari and Anne Engstrom

Date Received (in revised form): 28th March, 2008

\section{Pierre Berthon}

is the Clifford F. Youse Chair of Marketing at Bentley College. Professor Berthon's teaching and research focuses on electronic commerce, marketing information processing, organization and strategy, and management decision making. He has written over 90 academic papers. A number of his papers have won awards in the US and in the UK.

\section{Leyland Pitt}

is Professor of Marketing in the Segal Graduate School of Business, Simon Fraser University, Vancouver, Canada, and Senior Research Fellow at the Leeds University Business School, Leeds, United Kingdom. His work has appeared in journals such as California Management Review, Sloan Management Review and MIS Quarterly, in which he also served as Associate Editor.

\section{Deon Nel}

is Senior Lecturer in Marketing in the Department of Marketing, Deakin University, Melbourne, Australia. His research and teaching have focused on services and e-business, and his work has appeared in such journals as the European Journal of Marketing, Journal of Business Ethics, and the Journal of Managerial Psychology.

\section{Esmail Salehi-Sangari}

is Professor and Chairman of the Division of Industrial Marketing and e-Commerce at Lulea University of Technology in Sweden. He is currently researching on international organisational buying behaviour, marketing research and the marketing of small and mediumsized enterprises.

\section{Anne Engstrom}

is Assistant Professor in the Division of Industrial Marketing and e-Commerce at Lulea University of Technology in Sweden. Her PhD in e-Commerce assessed performance within business-to-business e-marketplaces.

\begin{abstract}
This paper serves to specify and ground research into interfunctional integration in a wider theoretical context with particular reference to the interaction between technology and marketing in the biotechnology sphere. The general and specific problem areas are specified as those of interfunctional relations and the dyadic relationship between marketing and biotechnical managerial functions in particular. The contextual/organisational generative mechanisms that are likely to keep interfunctional relations at the centre of scholarly attention for some time are explored from the perspective of cybernetic theory. The law of requisite variety states that in an effective open system environmental variety is matched by internal structural variety. As organisations are faced with ever more turbulent,
\end{abstract}

Correspondence: Pierre Berthon, Bentley College, 175 Forest Street,

Waltham, MA 02452, USA

Tel: +17818913189

Fax: +17817886456

E-mail: pberthon@bentley.edu 
and complex environments, this must be matched by an increased internal complexity within the organisation. The two modes of response, namely holographic and mechanistic, both highlight the need to further our understanding of interfunctional differences. Having established the problem and its genesis, a specific research agenda is outlined as the exploration of the interfunctional differences from a decision-making perspective. Journal of Commercial Biotechnology (2008) 14, 213-224. doi:10.1057/jcb.2008.12; published online 13 May 2008

Keywords: environmental turbulence, interfunctional integration, holographic response, mechanistic response

\section{INTRODUCTION}

Organisations can be conceptualised as systems that reify abstract ideas into tangible products or services. This takes place within a given environment that, according to contingency theory, organisations have to 'fit' in order to endure. ${ }^{1,2}$ Turbulent environments have placed enormous adaptive pressures upon organisations. To survive, organisations have evolved increased internal differentiation, typically clustered along functional lines. This, coupled with the need for greater flexibility, places increasing pressure to integrate and has led to a slowly rising interest in interfunctional relations - in both theory and practice. This is especially true in many areas of high-technology enterprise, and biotechnology is a case in point. In the case of a simple consumer goods firm for example, the roles of functions such as marketing on the one hand and technology and operations on the other will be especially clear. Marketing will determine customer needs, and then instruct technology and operations to conceptualise and produce these offerings. In many biotechnology companies on the other hand, the roles will be far less clear. Most of the investment would have been devoted to research and development $(\mathrm{R} \& \mathrm{D})$ and the acquisition of technical and scientific skills. The role of marketing will be unclear, and even delayed until the firm really has something to offer.

Research into interfunctional integration in the wider management context needs to be specified and positioned, for it is problem driven and a problem is always a function of its time and place. This is the focus of our paper. The general and specific problem areas are specified as those of interfunctional relations and the dyadic relationship between marketing and biotechnical managerial functions. The contextual/organisational generative mechanisms that are likely to keep interfunctional relations at the centre of scholarly attention for some time are explored from the perspective of cybernetic theory. Having established the problem and its genesis, the specific research agenda is outlined as the exploration of the interfunctional differences from a decisionmaking perspective. What follows is a more detailed exposition of how and why the problem has arisen and why it is likely to hold managers' and academics' attention for some time to come.

\section{WHY STUDY INTERFUNCTIONAL RELATIONS?}

To state a problem is not to understand it; understanding comes not from discovering a problem's present appearance but remembering its genesis. Typically the first step in research is the statement of the problem. Any attempt to investigate or provide answers, however, should be prefaced by the deeper question as to the problem's genesis. Without this vital second stage one is left with little or no idea of the likely magnitude or temporal durability of the problem. Thus, rather than assuming that the increased interest in interfunctional relations, 
what follows is a structured attempt to explain why this is so and why it is likely to become a growing rather than a declining area of concern. What ensues is an exposition of the present business environment, then, rather than leap from context to problem, glossed over in most discussions of interfunctional relations (eg Konijnendijk, ${ }^{3}$ Crittenden et al., ${ }^{4}$ Saghafi et al. ${ }^{5}$ ), a conceptual framework is provided to explain why different types of organisation are emerging and the differing problems these pose to interfunctional relations and the study thereof.

\section{THE CHANGING ENVIRONMENT}

In the changing environment of the last three decades, marketing has faced a serious challenge to its strategic and organisational roles (eg Achrol, ${ }^{6}$ Bennett and Cooper, ${ }^{7}$ Day, ${ }^{8}$ Hayes and Abernathy, ${ }^{9}$ Webster $^{10}$ ) and indeed to its conceptual and epistemological status.

The debate in the 1990s over "what is marketing?' (eg Hunt, ${ }^{11}$ Albaum $^{12}$ ) attests to a gnawing uncertainty and the ongoing bricolage of reworking tropes and aphorisms in an effort to securely locate the discipline in a coherent philosophy.

For heuristic purposes it is useful to speak of changes occurring at the physical, biological, social and mental levels. On a physical level the world conceived (and perceived!) as given, solid and 'out there' has been questioned by physicists: the closer one inspects the material world, the more elusive the matter becomes. ${ }^{13}$ Our whole relationship with the bio-sphere is being questioned and re-evaluated by the potentially growing ecological crisis. On a social level, the rapidly changing and evolving nature of society has thrown into question the entire notion of a fixed order, fixed structures and fixed relationships. Indeed, there 'is a nascent consensus that irreversible changes are occurring at an accelerating pace in the socioeconomic and political structures we have inherited for the post-war era, as well as in our relationship with the biosphere' ${ }^{14}$ On a conceptual level fixed ideas and fixed theories are proving ephemeral; the problem of reflexivity gnaws at the heart of reason - we stand on the edge of madness or freedom: we stand as it were are staring ourselves in the face - but have until now been innocent of our own features (ie we have not been aware of the precarious nature of our own epistemology). We seem to be slipping to an epistemological quagmire; or is it that our epistemology, born in another time and place, is blinding us to new vistas?

The new economic environment, variously denominated the 'postindustrial' economy, the 'service' economy, the 'information' economy, the 'global' economy and indeed the 'postmodern' economy is one characterised by ambiguity, paradox and chaos (eg Bell, ${ }^{15}$ De Greene ${ }^{16}$ ). Huber ${ }^{17}$ grouped the various characteristics of the emerging environments of the late 20th century under three broad rubrics: diversity, turbulence and knowledge. Environmental diversity corresponds to the degree of similarity or difference between elements of an environment. ${ }^{18}$ Turbulence is defined as the loss of the stable state, or a state where the ground itself is in motion; turbulence comprises and is the result of increasing technological change, interconnectedness and interdependence. ${ }^{19}$ Finally, knowledge (information about information) is replacing capital and energy as the primary wealthcreating asset, ${ }^{15,20}$ and this is particularly true in the field of biotechnology ventures. There is general consensus that diversity, turbulence and knowledge will all increase at exponential than at linear rates, producing widespread qualitative change.

\section{RESPONSES TO THE CHANGING ENVIRONMENT FROM THE PERSPECTIVE OF CYBERNETICS}

The principle of requisite variety ${ }^{21,22}$ argues that for a system to deal effectively with 
variety encountered in its external environment, it must possess a corresponding degree of internal variety. That is, in order for an organisation to cope with the problems, demands and opportunities presented in a given market and wider context, variety equal to that found in the context must be included within the system: simply, for ongoing survival internal variety must mirror external variety.

As outlined above, turbulent environments (and biotechnology firms are at play in these) are characterised by increasing rates of nonlinear change, an information explosion and increasing diversity. Simply in cybernetic terms they exhibit high degrees of variety. This in turn demands organisations with a high degree of internal variety. Now, internal diversity takes two forms, which correspond closely to two root organisational metaphors: ${ }^{23,24}$ the machine and the hologram. Requisite variety in machine design corresponds to increasing differentiation and specialisation of parts and functions (the part becomes more and more unique, and less and less like the whole). This is the classic response outlined in contingency theory by Lawrence and Lorsch ${ }^{2}$ and corresponds to Emery and Trist's ${ }^{19}$ redundancy of part (wherein elements of a system proliferate). For holographic design requisite variety corresponds to increasing the flexibility, richness and potentiality of each of the parts. Simply, the part is enriched in that it develops the abilities of the whole: the whole is more accurately reflected in the part. This equates closely to Emery and Trist's ${ }^{19}$ redundancy of function (wherein elements of a system become multifunctional).

Thus, the principle of requisite variety suggests that faced with turbulence organisations will on the one hand become increasingly differentiated (both inter- and intra-organisationally) and specialised. On the other hand, organisations will increasingly build richness or potentiality into each of their constituent elements. It is perhaps appropriate to point out that these two approaches are not necessarily mutually exclusive, and can be thought of as complementary. The analogy of depth and scope is appropriate, with the mechanistic approach encouraging depth (differentiation and specialisation), and the holographic approach encouraging scope (richness and flexibility).

Mechanistic intra-organisational design will see a proliferation of functional departments and subdepartments, research and project teams, each becoming increasingly specialised and expert in terms of knowledge and skills in a particular area. This will also manifest as an inter-organisational phenomenon where functions become increasingly specialised but independent, held together in network organisations. Holographic inter-organisational design will encourage multi-skilling, interchange ability, interdepartmental teams and other mechanisms to enhance flexibility by introducing to a greater extent the abilities of the whole into each of its parts. The argument is summarised in Figure 1.

Finally, it should be pointed out that organisations comprise, in part, their environment: they are thus the object and the subject of evolution. Strictly speaking it is only half of the story to say that organisations respond to their environments: they also create and determine them. ${ }^{19,25,26}$ This principle of codetermination, developed from the work of Bateson, ${ }^{27}$ suggests that in the case of turbulence at least, the relationship between organisation and environment is of the nature of a positive feedback or deviation amplification loop (illustrated in Figure 1 with $\mathrm{a}+$ ). Simply put, responses to turbulence create more of the same. Turbulence is likely to be here to stay: the only constant is change.

\section{EMERGING ORGANISATIONAL FORMS AND THE CHANGING ROLE OF THE MARKETING FUNCTION}

What cybernetics predicts from theory has been seen to occur in practice. Indeed, there 


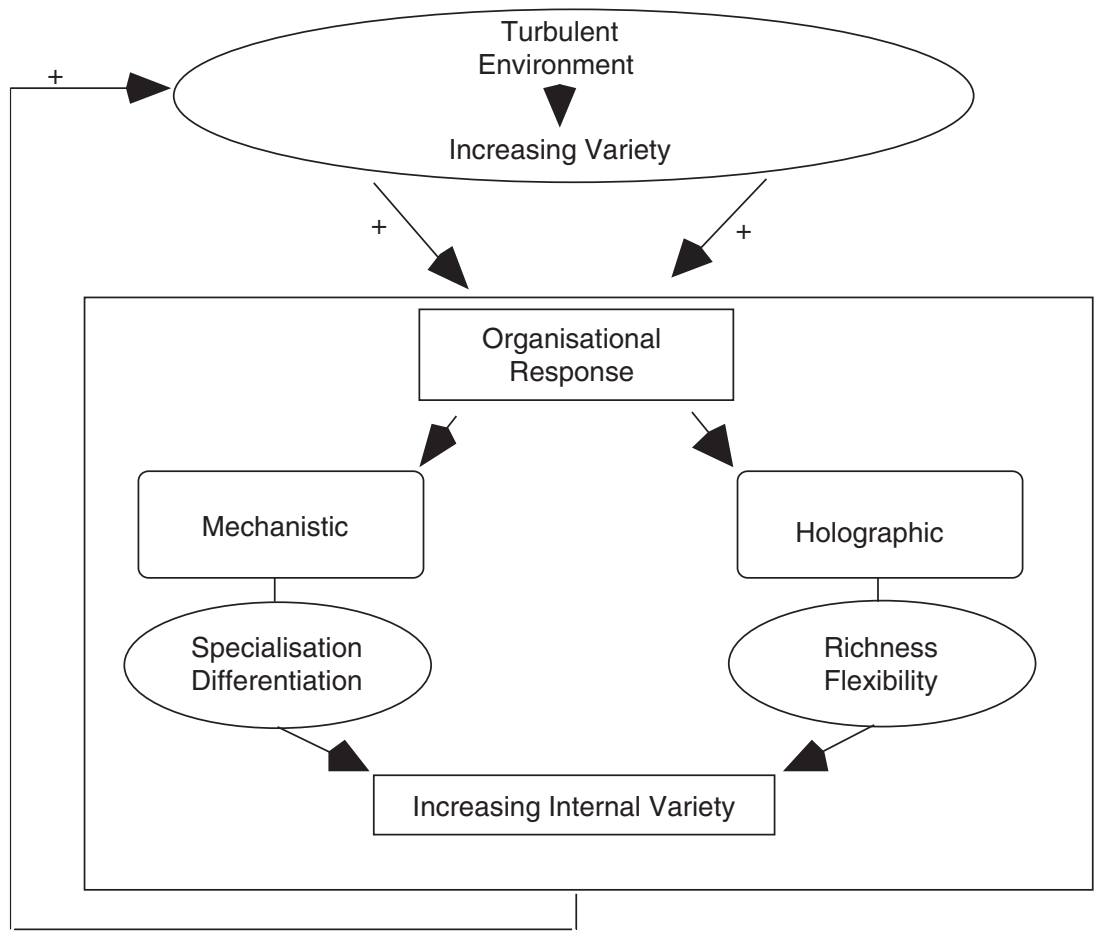

Figure I: Organisational responses to environmental turbulence

has been increasing attention given to emerging forms of organisation and changes in the marketing function. For example, Achrol $^{6}$ reviews the various forms of marketing organisation emerging in response to the turbulent environment. Webster ${ }^{10}$ charts the changing role of marketing within the corporation. Glazer and Weiss ${ }^{28}$ investigate the relationship between different modes of marketing planning and time sensitivity of information in a simulated turbulent environment. Capon and Glazer ${ }^{29}$ present the case for closer coalignment between marketing and technology as a route to success in turbulent environments. For convenience these organisational changes will be briefly reviewed in terms of macroorganisational level responses and microintra-organisational level responses.

\section{MACRO-ORGANISATIONAL LEVEL RESPONSES}

One extreme mechanistic response to turbulence is vertical disaggregation. ${ }^{30}$ Here, the division of labour and task manifests as division and specialisation of business functions into separate autonomous organisations. These in turn recombine in network organisations, ${ }^{30}$ held together and coordinated by market-driven focal organisations. Building on the work of Cummings $^{31}$ and Achrol et al., ${ }^{18}$ Achrol $^{6}$ extends the notion of transorganisational systems of exchange to the theory of the transorganisational firm, where the marketing exchange company becomes the organising hub for market information and complex exchanges. On a system level, however, the network organisation ${ }^{30}$ or transorganisational firm $^{6}$ has holographic-type response characteristics. Here, flexibility is a property of the network rather than of the individual disaggregated elements, which themselves become ever more specialised (the mechanistic response). Partnerships, strategic alliances and joint ventures can all be seen as steps towards network organisations. ${ }^{10}$ Even these firms that came together with the initial objective of 
retaining broad general organisational capabilities, quickly find themselves becoming focused and specialised in their core activities. ${ }^{10}$ The matrix organisation was one attempt to combine specialisation and flexibility, specifically through functional ambidexterity, and can be seen as a holographic-type response. Despite being a conceptually elegant solution, some, however, felt that it was cumbersome in practice and failed on the critical criteria of strategic flexibility. In contrast, others (eg Peters ${ }^{32}$ Bartlett and Ghoshal ${ }^{33}$ ) have evolved the concept, and it seems that proclamations of the matrix organisation's demise were premature. The matrix organisation still thrives, often in modified and hybrid forms, and often under different names. For example, Hurst $^{34}$ uses the term the 'woven' matrix organisation, and Ford and Randolph ${ }^{35}$ the terms the 'mixed' or 'overlay' organisation.

One key aspect of the holographic approach to variety is the capacity to selforganise. ${ }^{23}$ Thus, organisations, rather than be designed, emerge spontaneously in response to a given situation. Ad hoc organisations ${ }^{36}$ and synthetic organisations ${ }^{37}$ are examples of spontaneous organisation. These emerge in response to crises or as the result of serendipity and are typically highly ephemeral in nature or quickly evolve and adapt through the more formal mechanistic response.

\section{MICRO-INTRA- ORGANISATIONAL RESPONSES}

Organisations continue to differentiate internally, in a mechanistic mode, in response to turbulence. This is especially the case in knowledge-rich environments, such as advanced biotechnology markets, where a proliferation of information, complex knowledge and theoretical structures, and concomitant high skill levels result in increasing specialisation of function. In other areas however, holographic modes of response are being realised. For example, there is an increasing move towards multi-skilling, the use of interfunctional groups and temporary project teams (eg Harrigan ${ }^{38}$ ) and various types of autonomous or semi-autonomous workgroups. ${ }^{39}$ Further, there is a slow but perceptible democratisation of the workplace wherein decision making is distributed across all organisational members rather than focused in the hands of a few specialists. ${ }^{23}$ The Japanese 'Ringi' system of collective decision making is one specific example. ${ }^{40}$ Indeed, there is a slow progression towards coordination without hierarchy ${ }^{41}$ and heterarchical forms of organisation, which is entirely consistent with a holographic response to complexity. The general concern for decentralisation of authority, job rotation and multi-skilling is reflected in the marketing literature (eg Crittenden et al., ${ }^{4}$ Ruekert et al., ${ }^{42}$ Carroad and Carroad ${ }^{43}$ ).

With specific reference to marketing, interesting patterns are emerging. First, marketing is becoming a line function rather than a support function. Concomitant with this, Webster ${ }^{10}$ argues that marketing is becoming an organisation wide culture, strategy and tactic. Whether marketing as a distinct management function remains in the long term is less clear - indeed, whether it is necessary in the biotechnology company, a least in its narrowly defined commercial and communication sense, is debatable. Certainly, the marketing function of keeping the organisation (network or otherwise) informed about the customer will endure ${ }^{10}$ but whether it will remain distinct is highly uncertain (eg McKenna ${ }^{44}$ ). For example, it is apparent that the distinction between marketing and strategy is becoming more and more tenuous. ${ }^{45}$ The typology of responses is summarised in Table 1.

\section{THE RESULTING FOCUS ON INTERFUNCTIONAL RELATIONS}

As has been suggested, there are two responses to turbulence that correspond to 
Table I: Mechanistic and holographic responses to turbulence at macro and micro levels

\begin{tabular}{lll}
\hline & Mechanistic & Holographic \\
\hline Macro-level & $\begin{array}{l}\text { Vertical disaggregation } \\
\text { Strategic alliances } \\
\text { Network } \\
\text { organisations }\end{array}$ & $\begin{array}{l}\text { Matrix organisations } \\
\text { Ad Hoc organisations }\end{array}$ \\
Micro-level & $\begin{array}{l}\text { Job specialisation and } \\
\text { differentiation }\end{array}$ & $\begin{array}{l}\text { Job rotation } \\
\text { Multi-skilling }\end{array}$ \\
\hline
\end{tabular}

mechanistic design and holographic design principles. The former with its emphasis on depth (specialisation and differentiation) raises the problem of integrating disparate elements. The latter, with its focus on scope, raises the problem of reconciling quite different mindsets or views of the world within groups or indeed within the individual. Thus, from both perspectives the need to understand differences in functions (whether these be social bodies (functions, groups, teams or individuals) or cognitive bodies (models, cognitive schema, theories and paradigms) becomes paramount.

It can be argued that if the same individual performs two or more functions, the need to understand the differences between the functions is unimportant. A cursory glance at education, however, raises the question of why it is that people quickly specialise or develop preferences for, and excel in either art or science when they are exposed to both. Only exceptional individuals manage to do both as each demands different brain functions, different frames of mind and indeed different types of intelligence. Moreover, marketing and technical/scientific functions cannot simply be reduced to a body of knowledge - they are not simply a corpus of facts that can be learnt in the same way a program is loaded into a computer. Rather, each is better conceptualised as entire gestalts of thought and action. This perspective has long been mooted in the social sciences under the nomenclature of discourse. A discourse is a set of ideas and practices that informs our ways of interacting with a particular phenomenon. A discourse is embedded in social practice and thus cannot be reduced to either theory or practice: it encompasses both. A discourse is more than a way of seeing - it informs social action and thus is enacted. Action reproduces the conditions necessary for a way of seeing. The term discourse is similar to that of praxis (the Greek term for 'action' or 'practice') as used in the early philosophy of Marx. ${ }^{46}$ Praxis is defined as the unity of theory and practice.

Thus the difference between marketing and other functions cannot be reduced either to theory or action. The disciplines are not simply a way of seeing or a way of action, rather they are intact worlds of being that do not entirely overlap. From this perspective the differences between functions are not trivial and will not be easily overcome. This highlights the need to find out how and why functions differ, and not on a trivial content level or a broad definition level (each of which produce little more than tautologies). What needs to be more clearly understood are the decision-making processes whereby different managers construct, interpret and enact their functional worlds.

Indeed, there is some research to suggest that the holographic approach of multi-skilling and interfunctional roles is not as simple to implement as protagonists suggest.

Organisational role stressors, such as role ambiguity and role conflict, ${ }^{47}$ are greatly exacerbated in a holographic approach in providing requisite variety. Both have been found to be detrimental to organisational effectiveness. ${ }^{48}$ Indeed, functional ambidexterity appears very difficult to cultivate. ${ }^{6}$ Design approaches such as matrix organisations, which attempt to formalise functional ambidexterity have, as previously cited, proved difficult to realise in practice. ${ }^{49}$

\section{THE RESEARCH QUESTION}

Having demonstrated the continued importance of understanding the problem of 
interfunctional relations, the question that should guide research is delineated. As discussed above, the nature and role of the marketing function is changing. On the one hand, it is becoming an organisational wide 'world view' and culture, and on the other it seems set to remain a distinct function indeed the hub of future network organisations. ${ }^{6,10}$

Thus the broad question is: In what ways does the marketing function differ from other organisational functions with respect to key processes in biotechnology firms? The specific process that might be focused on is that of managerial decision making in a biotechnology environment. The above question can therefore be restated as: Does the marketing function differ from other organisational functions with respect to key decision-making processes in a biotechnology firm environment?

\section{A RESEARCH FOCUS: INTERFUNCTIONAL RELATIONS}

There exists a limited but growing body of theoretical and empirical research on interfunctional relations (eg Dutton and Walton, ${ }^{50}$ Van de Ven and Ferry, ${ }^{51}$ McCann and Galbraith, ${ }^{52}$ Souder $^{53}$ ) and specifically on the dyadic relationship between marketing and other functions. ${ }^{54-58}$ As the number of publications in this area attests, the subject is still in its nascent stage. Authors, however, would seem generally to agree upon two things. First, that there exist implicit differences and tensions between marketing and biotechnical issues regarding manufacturing operations, $\mathrm{R} \& \mathrm{D}$, information systems and accounting (eg Song and Parry, ${ }^{59}$ Kamath et al., ${ }^{60}$ Stevenson et al., $\left.{ }^{61}\right)$. Secondly, that increased co-ordination between functions will enhance organisational effectiveness; indeed, there is some empirical evidence to support this conjecture. ${ }^{62}$

Although other dyads have received attention (eg marketing and human resources $^{63}$ ) it is broadly what might be termed the marketing-technical dyad that seems to pose the greatest problems (in terms of organisational effectiveness) and has consequently received the most attention. 'Technical' as defined here, encompasses such functions as R\&D, production, operations, manufacturing, information systems. For example, Gupta and Rogers ${ }^{54}$ point out that one of the most significant causes of new product failure is the lack of integration of R\&D and marketing early in the innovation process, a finding supported by other researchers (eg Souder, ${ }^{53}$ Ruekert and Walker, ${ }^{55}$ Ruekert and Walker, ${ }^{56}$ Hauser and Clausing, ${ }^{64}$ Gupta et al. ${ }^{65}$ ). They argue that integration of these two functions is critical for a successful new product development and offer insights into how integration might be facilitated. Using a case study approach Moenaert and Souder ${ }^{66}$ investigated the use of extrafunctional information by R\&D and marketing personnel. They found that in contrast to $\mathrm{R} \& \mathrm{D}$, marketers relied more on intuition and less on hard information. Factual reports from $\mathrm{R} \& \mathrm{D}$ were poorly received by marketing. Saghafi et al. ${ }^{5}$ investigate the $\mathrm{R} \& \mathrm{D} /$ marketing interface in the telecommunications industry, focusing on five large companies. Their conclusion is that the interface poses significant problems and that integration between the two functions is far below the desired level. Lack of effective communication and involvement were cited as the greatest barriers to successful integration. Capon and Glazer ${ }^{29}$ in a theoretical paper present the case for integrating technology and marketing strategy. They argue that technological functions and marketing functions are two key elements that affect corporate success in rapidly changing environments and that technologically oriented marketing decisions at both a strategic and an operational level are essential for success in such contexts. St John and $\mathrm{Hall}^{62}$ in a survey of 15 companies found that the simultaneous use of a range of coordinating mechanisms (between marketing 
hierarchical. Forced integration of functions through whatever mechanism emphasises, however, reduces the need for enhancing understanding of how different functional groups differ with respect to key processes. One such process is that of decision making.

To date, inter-functional differences in decision making have received relatively little attention. Hambrick and Mason ${ }^{70}$ suggest that functional background has a significant influence on the decisions of members of top management teams. Moreover, within an organisation it has been demonstrated that 'output' functions such as marketing and sales have a greater influence on product and market development decisions than 'throughput' technical functions such as finance and production. ${ }^{71}$

Hutt et al. ${ }^{72}$ link strategic decision making with interfunctional relations. They point out that in the research on marketing decision making little or no attention has been paid to the interdependencies between marketing and other functions. By tracking strategy formulation across organisations they show the relative autonomy of the process and by implication how it cannot be understood by looking at individuals or departments in isolation. The importance of understanding how different departments interact is echoed by Jaworski and Kohli ${ }^{73}$ who demonstrate that the manner in which various departments interact is very important in determining the level of the market orientation of a business. ${ }^{74}$ Simply, interdepartmental conflict appears to reduce market orientation, and conversely connectedness appears to act as a catalyst.

\section{CONCLUSIONS AND RESEARCH DIRECTIONS}

The purpose of this review has been to revisit the issue of marketing organisation in the light of environmental instability and increasingly complex corporate responses, focusing particularly on interfunctional relationships between marketing and technical departments and functions in a biotechnology 
environment. The need for this focus was underlined by arguing that interfunctional relations may become a critical organisational problem as organisations seek to cope with growing environmental turbulence, diversity and knowledge expansion through task specialisation. This is especially true in the biotechnology business environment, where politicians demand solutions to problems that only biotechnology can solve; yet continually enact legislation that restricts what biotechnology firms can do to solve them. Simultaneously, the economic environment impacts on biotechnology firms at the start-up of established levels, and affects how they raise funding and use it, how they recruit and deploy talent, and how much they can expect to sell of a new product once it reaches the marketplace. Society also has its say, very often from a base of benign ignorance: simultaneously demanding miracle breakthroughs from the biotechnology industry while cowering in fear and in misguided perceptions of the consequences of some of its developments. Technology itself moves ahead at an astonishing pace, and biotechnology firms struggle to keep up with advances not only in their own fields but also in seemingly unrelated ones.

The thesis is that the field of cybernetics, and specifically its focus on the matching of internal and external variety, offers a useful and insightful conceptual framework for the analysis and study of this issue. The cybernetic framework provides the means to distinguish between mechanistic and holographic responses to environmental turbulence (suggesting the distinction between differentiation and specialisation for depth, and richness and flexibility for scope). To this is added the distinction between macro- and micro-level organisational responses. This framework is potentially insightful in classifying organisational responses to managing key marketing processes, and particularly in highlighting conflicts between processes in marketing and the technical functions within biotechnology firms.
The main research question identified is concerned with the degree and ways in which the marketing functions differ from others in key decision-making processes within the biotechnology enterprise. The initial proposal is that research should explore interfunctional differences concerned with differences between marketing and technical managers' perceptions of problems, on the grounds that the process of problem perception determines to a substantial degree the subsequent course of problem-solving action undertaken (eg Mintzberg et al. ${ }^{75}$ ). This should necessarily consider both organisational factors (ie job function), as well as individual psychological differences.

More detailed questions to study in this area include: differences between managers in their perception (or enactment) of the environment, and related informational behaviour); questions of problem isolation and definition by different functional specialists both in content but also in less tangible issues like time-frame; the development of frameworks for choice by different functional specialists, and the potential paradigm conflict between different disciplines; and, the actual processes of choice by different managers.

Detailed attention to these questions is justified for two main reasons. First, the better understanding of the dynamics of interfunctional behaviour may well provide a framework for analysing failures in coordination and performance for example in the technology/marketing interface in biotechnology firms, in providing 'seamless' service to support market strategies, and in adapting to the reality of the 'lean' supply chain. Secondly, that deeper understanding may also provide a source of better forms of interfunctional relationship management that are effective in balancing different types of integration mechanism to achieve different goals in the biotechnology industry.

\section{References}

1. Galbraith, J. (1973). Designing Complex Organizations, Addison-Wesley, Reading, MA. 
2. Lawrence, P. R. \& Lorsch, J. W. (1967). Organization and Environment, Harvard Graduate School of Business, Cambridge, MA.

3. Konijnendijk, P. A. (1993). Dependence and conflict between production and sales. Ind. Market. Manag. 22, 161-167.

4. Crittenden, V. L., Gardiner, L. R. \& Stam, A. (1993). Reducing conflict between marketing and manufacturing. Ind. Market. Manag. 22, 299-309.

5. Saghafi, M. M., Gupta, A. \& Sheth, J. N. (1990). $\mathrm{R} \& \mathrm{D} /$ marketing interfaces in the telecommunications industry. Ind. Market. Manag. 19, 87-94.

6. Achrol, R. S. (1991). Evolution of the marketing organization: New forms for turbulent environments. J. Marketing 55, 77-93.

7. Bennett, R. C. \& Cooper, R. G. (1981). The misuse of marketing: An American tragedy. Bus. Horizons 24, 51-61.

8. Day, G. S. (1992). Learning about markets, Report No. 91-117, Marketing Science Institute, Cambridge, MA.

9. Hayes, R. H. \& Abernathy, W. J. (1980). Managing our way to economic decline. Harvard Bus. Rev. 58, $67-77$.

10. Webster, F. E. (1992). The changing role of marketing within the corporation. J. Marketing 56(October), 1-17.

11. Hunt, S. D. (1992). Marketing is. J. Acad. Market. Sci. 20(3), 301-311.

12. Albaum, G. (1992). What is marketing? A comment on 'marketing is...'.J. Acad. Market. Sci. 20(4), 313-316.

13. Davies, P. \& Gribbin, J. (1992). The Matter Myth, Penguin, London.

14. Dobuzinskis, L. (1992). Modernist and postmodernist metaphors of the policy process: Control and stability vs. chaos and reflexive understanding. Policy Sci. 25, 355-380. Page 362 quoted.

15. Bell, D. (1973). The Coming of the Post-Industrial Society, Basic Books, New York.

16. De Greene, K. (1990). The turbulent field environment of sociotechnical systems: Beyond metaphor. Behav. Sci. 35, 49-59.

17. Huber, G. P. (1984). The nature and design of post industrial organizations. Mngt. Sci. 30, 69-76.

18. Achrol, R. S., Scheer, L. K. \& Stern, L. W. (1990). Designing successful transorganizational marketing alliances, Report No. 90-118. Marketing Science Institute, Cambridge, MA.

19. Emery, F. E. \& Trist, E. (1965). The causal texture of organizational environments. Hum. Relat. 18, 21-32.

20. Handy, C. (1994). The Empty Raincoat: Making Sense of the Future, Hutchinson, London.
21. Ashby, W. R. (1952). Design for a Brain, Chapman \& Hall, London.

22. Ashby, W. R. (1956). An Introduction to Cybernetics, Chapman \& Hall, London.

23. Morgan, G. (1983). Action learning: A holographic metaphor for guiding social change. Hum. Relat. 37(1), 1-28.

24. Morgan, G. (1986). Images of Organization, Sage, London.

25. Levins, R. \& Lewontin, R. (1985). The Dialectic Biologist, Harvard University Press, Cambridge, MA.

26. Ackoff, R. L. (1970). A Concept of Corporate Planning, John Wiley \& Sons, New York.

27. Bateson, G. (1979). Mind and Nature, Bantam Books, New York.

28. Glazer, R. \& Weiss, A. M. (1993). Marketing in turbulent environments: Decision processes and the time-sensitivity of information. J. Market. Res. 30(November), 509-521.

29. Capon, N. \& Glazer, R. (1987). Marketing and technology: A strategic coalignment. J. Market. 521(July), 1-14.

30. Miles, R. E. \& Snow, C. C. (1984). Fit, failure and the hall of fame. Calif. Manag. Rev. 26(1), 10-28.

31. Cummings, T. G. (1984). Transorganizational behavior, in Staw, B.M. and Cummings, L.L. (eds.), Research in Organizational Behavior 6, JAI Press, Greenwich, CT.

32. Peters, J. (1993). On structures. Manag. Decis. 31(6), 60-62.

33. Bartlett, C. A. \& Ghoshal, S. (1990). Matrix management: Not a structure, a frame of mind. Harvard Bus. Rev. 68(January): 11-19.

34. Hurst, D. K. (1991). Cautionary tales from the Kalahari: How hunters become herders (and may have trouble changing back again). Acad. Manag. Exec. 5(3), 74-86.

35. Ford, R. C. \& Randolph, W. A. (1992). Crossfunctional structures: A review and integration of matrix organization and project management. J. Manag. 18(2), 267-294.

36. Pondy, L. R. \& Mitroff, I. I. (1979). Beyond open system models of organization, in Staw, B. (ed.), Research in Organizational Behavior, JAI Press, Greenwich, CT.

37. Thompson, J. D. (1967). Organizations in Action, McGraw-Hill, New York.

38. Harrigan, K. (1985). Strategic Flexibility, Lexington Books, Lexington, MA.

39. Susman, G. (1976). Autonomy at Work, Praeger, New York.

40. Ouchi, W. (1982). Theory Z, Addison-Wesley, Reading, MA.

41. Chisholm, D. (1989). Coordination without Hierarchy: Informal Structures in Multiorganizational Systems, University of California Press, Berkeley, CA. 
42. Ruekert, R. W., Walker, O. C. \& Roering, K. J. (1985). The organization of marketing activities: A contingency theory of structure and performance. J. Marketing. 49(Winter): 13-25.

43. Carroad, P. A. \& Carroad, C. A. (1982). Strategic interface of R\&D and marketing. Res. Manag. 34(January), 28-33.

44. McKenna, R. (1991). Marketing is everything. Harvard Bus. Rev. 69(January-February), 65-79.

45. Morris, M. H., Pitt, L. F. \& Bromfield, D. (1994). Marketing as strategy: Beyond territorial boundaries. Futures 26(4), 391-402.

46. Kolakowski, L. (1981). Main Currents of Marxism 1, Oxford University Press, Oxford.

47. Keaveney., S. M. \& Nelson, J. E. (1993). Coping with organizational role stress: Intrinsic motivational orientation, perceived role benefits, and psychological withdrawal. J. Acad. Market. Sci. 21(2), 113-124.

48. Singh, J. (1993). Boundary role ambiguity: Facets, determinants, and impacts. J. Marketing 57, 11-31.

49. Davis, S. M. \& Lawrence, P. R. (1978). Problems of matrix organizations. Harvard Bus. Rev. 56(MayJune), 131-142.

50. Dutton, J. M. \& Walton, R. E. (1966). Interdepartmental conflict and cooperation: Two contrasting studies. Hum. Organ. 25, 207-220.

51. Van de Ven, A. H. \& Ferry, D. L. (1980). Measuring and Assessing Organizations, John Wiley, New York.

52. McCann, J. \& Galbraith, J. R. (1981). Interdepartmental relations. Handbook Organ. Des. 2, 60-84.

53. Souder, W. E. (1987). Managing New Product Innovation, Lexington Books, Lexington, MA.

54. Gupta, A. K. \& Rogers, E. M. (1991). Internal marketing: Integrating $\mathrm{R} \& \mathrm{D}$ and marketing within the organization. J. Serv. Market. 5(2), 55-68.

55. Ruekert, R. W. \& Walker, O. C. (1987). Marketing's interaction with other functional units: A conceptual framework and empirical evidence. J. Marketing 15, 1-19.

56. Ruekert, R. W. \& Walker, O. C. (1987). Interactions between marketing and R\&D departments in implementing different strategies. Strategic Manag. J. 8, 233-248

57. Szakonyi, R. (1988). Dealing with non-obvious source of problems related to selecting R\&D to meet customers future needs: Weaknesses within an R\&D organization's and within a marketing organization's individual operation. IEEE Trans. Eng. Mngt. 35(1), 37-41.

58. Olson, E. M. 1993. The marketing/manufacturing relationship within the new product development process. In: Cravens D.W. \& Dickson P. R. (eds.), 1993 AMA. Educators' Proceedings, Chicago: American Marketing Association. 4, pp. 280-286.

59. Song, X. M. \& Parry, M. E. (1992). The $\mathrm{R} \& \mathrm{D}$-marketing interface in Japanese high technology firms. J. Prod. Innovat. Manag. 9(2), 91-112.

60. Kamath, R. R., Mansour-Cole, D. M. \& Apana, R. (1993). Functional perspectives on innovations: The correlates of innovation in the marketing and manufacturing functions. IEEE Trans. Eng. Manag. 40(3), 293-299.

61. Stevenson, T. H., Barnes, F. C. \& Stevenson, S. A. (1993). Activity-based costing: An emerging tool for industrial marketing decision makers. J. Bus. Ind. Market. 8(2), 40-52.

62. St John, C. H. \& Rue, L. W. (1991). Co-ordinating mechanisms, consensus between marketing and manufacturing groups, and market place performance. Strategic Manage. J. 12(7), 549-555.

63. Glassman, M. \& McAfee, B. (1992). Integrating the personal and marketing functions: The challenge of the 1990's. Bus. Horizons 35(3), 52-59.

64. Hauser, J. \& Clausing, D. (1988). The house of quality. Harvard Bus. Rev. 66(May-June): 63-73.

65. Gupta, A. K., Raj, S. P. \& Wilemon, D. (1986). A model for studying R\&D marketing interface in the product innovation process. J. Marketing 50(2), 7-17.

66. Moenaert, R. K. \& Souder, W. E. (1990). An analysis of the use of extrafunctional information by $\mathrm{R} \& \mathrm{D}$ and marketing personnel: Review and model. J. Prod. Innovat. Mngt. 7(3), 213-229.

67. Mahajan, J., Vakharia, A. J., Pallab, P. \& Chase, R. B. (1994). An exploratory investigation of the interdependence between marketing and operations functions in service firms. Int. J. Res. Mark. 11(1), 1-15.

68. Lawler, E. (1992). Executive survey: Building relationships. Bus. Market. 77(9), 34.

69. Stam, A. \& Gardiner, L. R. (1992). A multiple objective marketing-manufacturing approach for order (market) selection. Comput. Opns. Res. 19(7), 571-583.

70. Hambrick, D. C. \& Mason, P. A. (1984). Upper echelons: The organization as a reflection of its top managers. Acad. Manag. Rev. 9(2), 193-206.

71. Hegarty, W. H. \& Hoffman, R. C. (1990). Product/ market innovations: A study of top management involvement among four cultures. J. Prod. Innovat. Manag. 7, 186-199.

72. Hutt, M. S., Reingen, P. H. \& Ronchetto, J. R. (1988). Tracing emergent processes in marketing strategy formation. J. Marketing 52(1), 4-19.

73. Jaworski, B. J. \& Kohli, A. K. (1993). Market orientation: antecedents and consequences. J. Marketing 57(July), 53-70.

74. Kohli, A. K. \& Jaworski, B. J. (1990). Market orientation: The construct, research propositions, and managerial implications. J. Marketing 54(2), 1-18.

75. Mintzberg, H., Raisinghani, D. \& Theoret, A. (1976). The structure of 'unstructured' decision processes. Admin. Sci. Quart. 21, 246-275. 
Reproduced with permission of the copyright owner. Further reproduction prohibited without permission. 